\title{
Association of total mixed ration particle fractions retained on the Penn State Particle Separator with milk, fat, and protein yield lactation curves at the cow level
}

\author{
M. Caccamo, ${ }^{\star 1}$ J. D. Ferguson,† R. F. Veerkamp,‡ I. Schadt, ${ }^{\star}$ R. Petriglieri,, ${ }^{*}$ G. Azzaro, ${ }^{*}$ A. Pozzebon, ${ }^{*}$ \\ and G. Licitra*§ \\ ${ }^{*}$ CoRFiLaC, Regione Siciliana, 97100 Ragusa, Italy \\ †School of Veterinary Medicine, University of Pennsylvania, Kennett Square 19348 \\ $\ddagger$ Animal Breeding and Genomics Centre, Wageningen UR Livestock Research, PO Box 65, 8200 AB Lelystad, the Netherlands \\ §Dipartimento di Scienze delle Produzioni Agrarie e Alimentari (DISPA), Agriculture Faculty, Catania University, 95123 Catania, Italy
}

\begin{abstract}
As part of a larger project aiming to develop management evaluation tools based on results from test-day (TD) models, the objective of this study was to examine the effect of physical composition of total mixed rations (TMR) tested quarterly from March 2006 through December 2008 on milk, fat, and protein yield curves for 25 herds in Ragusa, Sicily. A random regression sirematernal grandsire model was used to estimate variance components for milk, fat, and protein yields fitted on a full data set, including 241,153 TD records from 9,809 animals in 42 herds recorded from 1995 through 2008. The model included parity, age at calving, year at calving, and stage of pregnancy as fixed effects. Random effects were herd $\times$ test date, sire and maternal grandsire additive genetic effect, and permanent environmental effect modeled using third-order Legendre polynomials. Model fitting was carried out using ASREML. Afterward, for the 25 herds involved in the study, 9 particle size classes were defined based on the proportions of TMR particles on the top (19-mm) and middle (8-mm) screen of the Penn State Particle Separator. Subsequently, the model with estimated variance components was used to examine the influence of TMR particle size class on milk, fat, and protein yield curves. An interaction was included with the particle size class and days in milk. The effect of the TMR particle size class was modeled using a ninth-order Legendre polynomial. Lactation curves were predicted from the model while controlling for TMR chemical composition (crude protein content of $15.5 \%$, neutral detergent fiber of $40.7 \%$, and starch of $19.7 \%$ for all classes), to have pure estimates of particle distribution not confounded by nutrient content of TMR. We found little effect of class of particle proportions on milk yield and fat yield
\end{abstract}

Received December 16, 2012

Accepted November 26, 2013.

${ }^{1}$ Corresponding author: caccamo@corfilac.it curves. Protein yield was greater for sieve classes with 10.4 to $17.4 \%$ of TMR particles retained on the top (19$\mathrm{mm}$ ) sieve. Optimal distributions different from those recommended may reflect regional differences based on climate and types and quality of forages fed.

Key words: lactation curve, particle size, total mixed ration, test-day model

\section{INTRODUCTION}

Roughage in ruminant diets stimulates chewing and saliva production, which helps buffer the rumen against severe $\mathrm{pH}$ reduction, which may occur in high-producing dairy cows fed energy-dense rations. Both quantity and physical form of the roughage is important to support normal rumen function (Balch, 1971; Allen, 1997). A minimal threshold of total chewing time per day, particularly time spent in rumination, is correlated with adequate physical form of roughage in a diet and is associated with the formation of a mat of coarse material in the rumen (Balch, 1971). The chemical constituent of roughage associated with chewing and mat formation is NDF, plant residues insoluble in neutral detergent, after Van Soest et al. (1991) and Allen (1997). To ensure adequate fiber, the NRC (2001) recommends that diets composed primarily of corn silage and alfalfa haylage as forage sources and dry corn as the main concentrate source contain a minimum of $25 \% \mathrm{NDF}$ on a DM basis and $76 \%$ of the NDF from forage. Typical values for NDF in corn silage and alfalfa haylage may range from 38 to $46 \%$ of DM and from 36 to $45 \%$ of DM, respectively. Thus, forage content of diets may vary from 43 to $58 \%$ of total DM consumed to meet these guidelines. However, these guidelines do not specify a particle size, which can vary greatly depending on several factors such as the chop length set at harvest or the duration of mixing of forages within a TMR, which may ultimately influence the effectiveness of the NDF to maintain a rumen mat and adequate chewing activity. 
Adequate NDF is important in dairy rations to support normal rumen activity and prevent milk fat depression and health problems associated with rumen acidosis. Rations may contain adequate NDF but be processed so finely that normal rumen activity cannot be maintained. Mertens (1997) combined the concept of adequate chemical NDF with physical form to define physically effective NDF (peNDF) as a measure that captures the physical characteristics of fiber by accounting for particle length and NDF content. Physically effective NDF promotes chewing and the flow of salivary buffers to the rumen to maintain a normal rumen milieu (Mertens, 1997). Mertens (1997) defined long grass hay as $100 \%$ peNDF and ranked peNDF in chopped forages, grains, and byproduct feeds in relation to chewing activity of long grass hay at comparable NDF contents. As mean particle size decreases, peNDF decreases, as does chewing time and rumen $\mathrm{pH}$ because of a reduction in saliva production and its buffering action (Woodford and Murphy, 1988; Grant and Colenbrander, 1990a,b).

Physically effective fiber is the fraction of the diet that stimulates chewing (NRC, 2001), but standard guidelines are qualitative in nature. Because forage provides the majority of long particles in a dairy ration and the majority of NDF, adequate peNDF and particle size are often used interchangeably to describe adequate fibrosity of dairy rations; however, these terms are not entirely interchangeable. Forages may be finely chopped, providing adequate NDF and forage content of diets but inadequate particle size. Thus, peNDF is either estimated based on guidelines of average theoretical chop length of hays, haylages, and corn silages or based on particle distribution of the roughage, assuming uniformity of NDF content across particles. However, particle distribution of roughages and TMR may contain varying content of NDF (Kononoff et al., 2003); therefore, peNDF may not be consistent with estimates based on roughage or TMR particle distribution. It is not practically possible to measure the NDF content of particles separated by particle length within feeds or TMR. Therefore, forage content, NDF content, and particle distribution are typically described to adequately account for rumen effectiveness of long particles and roughages in dairy rations.

A challenge has been to establish a method to define adequate particle length in dairy rations that is simple and repeatable. Lammers et al. (1996) developed a simple field-usable device to estimate particle size of forages and TMR (Penn State Particle Separator, PSPS). The PSPS was designed to allow separation of feed particles by a shaking motion duplicating vertical sieving. Initially 2 screens, $19.0 \mathrm{~mm}$ and $8.0 \mathrm{~mm}$, and a pan were used to estimate mean particle size. Since that publication, the PSPS has been modified to include a third screen, $1.18 \mathrm{~mm}$ in size (Kononoff et al., 2003). Guidelines published by Heinrichs and Kononoff (2002) recommend that adequate chewing is maintained when a TMR contains 2 to $8 \%$ of material on the top screen $(19.0 \mathrm{~mm}), 30$ to $50 \%$ of material on the middle screen (8 mm), 30 to $50 \%$ of material on the lower screen (1.18 $\mathrm{mm}$ ), and $<20 \%$ of material in the pan. Most authors have focused on the total feed material retained on the top 2 screens as the physically effective material in dairy rations. In fact, Schadt et al. (2012) found that swallowed boli from hay particles retained on the top 2 screens contained particles sufficiently long enough to contribute to long particles in the rumen. Particles retained on the 1.18-mm screen when masticated and swallowed were too fine to contribute to formation of the rumen mat.

Various approaches have been used to estimate peNDF from particle distribution in the PSPS. The simplest is based on as-fed distribution of feed particles, with the proportion retained on the top 2 screens serving as an estimate of the peNDF. Further refinements include DM retained on the top 2 screens times the NDF content of the entire diet as an estimate of peNDF, or to estimate peNDF as the proportion of NDF retained on the top 2 screens as a proportion of total NDF. In addition, mean geometric particle size has been calculated based on proportions retained on the 3 screens and pan, and this has been used to evaluate chewing activity and mean ruminal $\mathrm{pH}$. An accurate and repeatable method to estimate peNDF and adequate particle length of TMR on dairy farms is still to be determined.

It is generally recognized that rumen particles $>1.18$ $\mathrm{mm}$ are large particles retained in the rumen and are an index of peNDF (Mertens, 1997). However, Kononoff and Heinrichs (2003a,b) and Maulfair and Heinrichs (2010) found that particles larger than those retained on a 1.18-mm screen were not a critical measure of the effectiveness of chewing activity, but larger particles, either $>8 \mathrm{~mm}$ or $>19 \mathrm{~mm}$, were more indicative of the effectiveness of fiber in dairy rations. In addition, Kononoff and Heinrichs (2003a) observed that particles $>1.18$ $\mathrm{mm}$ ranged from 42.9 to $54.1 \%$ of fecal particles in cows consuming cottonseed hull-based diets, suggesting that, in high-producing dairy cows, the rumen threshold size is $>1.18 \mathrm{~mm}$. It may be that cows consuming higher DM amounts from wet forages will pass larger particles than observed by Poppi (1980), who investigated fecal particles in cattle consuming dry hay diets at lower DMI. In fact, fecal particles correspond to the size of particles leaving the rumen, as little reduction in size occurs in the distal gastrointestinal tract. Fecal particle size should perhaps be included in an assessment of 
dietary particle size to more accurately characterize peNDF for dairy cattle.

The objective of this study was to assess the association of particle size in TMR estimated using the Penn State Particle Separator with production of milk, fat, and protein on a representative sample of Ragusa dairy farms, while controlling for nutrient content.

\section{MATERIALS AND METHODS}

\section{Data}

Production data for milk $(\mathrm{kg})$, fat $(\mathrm{g})$, and protein (g) and TMR information were collected from 25 herds located in Ragusa province (Italy) from 2006 through 2008 and formed a data set including 46,531 test-day (TD) records from 3,554 cows. This data set was used to estimate association of random individual curves for milk yield with particle size distribution of diets. To estimate variance components for the genetic effects more precisely, a larger data set with more animals than those with known TMR was necessary. A data set including 241,153 TD records from 9,809 animals in 42 herds recorded from 1995 through 2008 was supplied by the local milk recording agency (APA Ragusa, Italy) and used to estimate variance components for milk $(\mathrm{kg})$, fat $(\mathrm{g})$, and protein $(\mathrm{g})$ yields using a random regression TD model.

For the 25 herds included in the reduced data set, TMR samples were collected every 3 mo from March 2006 through December 2008, sieved through the PSPS according to the procedure of Heinrichs and Kononoff (2002), and analyzed for soluble nitrogen (Licitra et al., 1996), ADL (Goering and Van Soest, 1970), ADF (Goering and Van Soest, 1970), and starch (AOAC International, 1998; method 996.11). Feeds were dried overnight at $105^{\circ} \mathrm{C}$ to obtain $\mathrm{DM}$ and combusted in a muffle furnace at $550^{\circ} \mathrm{C}$ for $4 \mathrm{~h}$ to obtain ash content and OM. Nitrogen content was determined by a Kjeldahl procedure with $\mathrm{Cu}^{2+}$ as a catalyst and multiplied by 6.25 to obtain CP. Amylase-treated NDF (aNDF) was determined according to Mertens (2002) using sodium sulfite and heat-stable $\alpha$-amylase (Sigma-Aldrich, Steinheim, Germany). All chemical analyses were expressed on a DM basis. Diets were also evaluated using CPM Dairy (version 3.0.8; Cornell University, Ithaca, NY; University of Pennsylvania, Kennett Square, PA; and Miner Agricultural Research Institute, Chazy, NY) to verify ration balancing. Residues on the 3 sieves (19 mm, 19_PSPS; $8 \mathrm{~mm}, 8$ 8_PSPS; $1.18 \mathrm{~mm}$, 1.18_PSPS) and the bottom content were weighed and proportions on total weight were calculated on an as-fed basis. Afterward, peNDF was calculated as the proportion of TMR retained on the 19_PSPS and 8_PSPS screens times the ration NDF content (Yang et al., 2001). The mean geometric particle length was calculated based on the proportion of particles $>8 \mathrm{~mm}$ in size (Armentano and Taysom, 2005).

\section{Particle Size Classes}

Overall means and standard deviations for particle distribution on the 4 PSPS sieves and nutrient content were calculated (Table 1). In addition, ranges for nutrient content and particles on the 19_PSPS and 8_PSPS sieves were plotted and examined for uniformity of distribution. Heinrichs and Kononoff (2002) recommend that $\leq 8 \%$ of TMR particles be collected on the 19_PSPS screen of the particle separator. Because of the distribution of 19_PSPS sieve particles in this data set, categories of $<10.4 \%, 10.4$ to $17.4 \%$, and $\geq 17.5 \%$ were made. Second, peNDF recommendations are based on the sum of the top 2 screens, and Heinrichs and Kononoff (2002) recommend that 30 to $50 \%$ of particles be on the 8_PSPS and 1.18_PSPS sieves and up to $20 \%$ of particles be on the bottom sieve. Given a 19_PSPS maximum of $10.4 \%$ and a bottom maximum of $20 \%$, then $34.9 \%$ for the 8 _PSPS and 1.18_PSPS screens are allowable solutions. Therefore, the 8_PSPS screen was divided into classes based on $<30.1,30.1$ to 35.6 , and $\geq 35.7 \%$ of TMR retained particles. This resulted in 9 classes of sieve categories based on 19_PSPS and 8_PSPS screen classifications.

\section{Association of Particle Size Classes with Feed Compositions and Production}

To examine differences in $\mathrm{CP}, \mathrm{NDF}$, starch, ash, ADL, ADF, and ether extract (EE) across particle size classes, the following mixed model, with herd nested within class as the repeated term with covariance matrix set to autoregressive(1), was applied using SAS software (version 9.1.3, SAS Institute Inc., Cary, NC):

$$
Y_{j}=u_{i}+\operatorname{class}_{j}+\operatorname{herd}_{k}\left(\operatorname{class}_{j}\right)+\varepsilon_{j k l},
$$

where $Y_{j}=$ mean of interest for PSPS, CP, NDF, starch, ash, ADL, ADF, and EE; $\mathrm{u}_{\mathrm{i}}=$ overall mean for the ith item; $\operatorname{class}_{\mathrm{j}}=$ jth class based on upper and middle sieve categories (1 to 9$) ; \operatorname{herd}_{\mathrm{k}}\left(\right.$ class $\left._{\mathrm{j}}\right)=\mathrm{kth}$ herd nested in the jth particle size class ( 25 herds); and $\varepsilon_{\mathrm{jkl}}=$ residual, random error.

Actual TD records for milk and milk component yields across particle size classes were examined using the above model with cow nested within herd as a repeated effect. 
Table 1. Mean dietary composition (\% of DM unless otherwise noted) and Penn State Particle Separator (PSPS) distribution for 25 farms in the Ragusa province of Sicily

\begin{tabular}{|c|c|c|c|c|}
\hline Item & Mean & $\mathrm{SD}$ & Minimum & Maximum \\
\hline $\mathrm{CP}$ & 15.2 & 1.53 & 11.1 & 18.6 \\
\hline Soluble protein (\% of CP) & 32.8 & 8.84 & 11.2 & 60.6 \\
\hline NDF & 40.7 & 4.26 & 25.0 & 50.1 \\
\hline $\mathrm{ADF}$ & 23.8 & 3.16 & 13.7 & 32.1 \\
\hline Starch & 19.7 & 3.56 & 7.6 & 32.3 \\
\hline $\mathrm{NFC}^{1}$ & 32.0 & 4.02 & 22.1 & 49.9 \\
\hline ADL & 4.2 & 1.05 & 1.0 & 8.4 \\
\hline Ether extract (EE) & 4.3 & 1.21 & 2.7 & 7.3 \\
\hline Ash & 8.0 & 0.85 & 6.1 & 11.1 \\
\hline \multicolumn{5}{|l|}{ Proportion on PSPS (\%) } \\
\hline Top screen; $19.0 \mathrm{~mm}$ & 14.7 & 8.05 & 1.4 & 38.8 \\
\hline Middle screen; $9.0 \mathrm{~mm}$ & 33.7 & 7.78 & 13.1 & 58.5 \\
\hline Lower screen; 1.6 mm & 35.5 & 6.00 & 20.4 & 49.1 \\
\hline Bottom pan & 16.2 & 5.02 & 1.9 & 28.1 \\
\hline peNDF $^{2}$ & 19.8 & 4.88 & 10.8 & 33.5 \\
\hline $\mathrm{GMPL}^{3}$ & 6.3 & 1.11 & 3.9 & 9.3 \\
\hline
\end{tabular}

${ }^{1}$ Calculated as $100-\mathrm{CP}-\mathrm{NDF}-\mathrm{EE}$ - ash.

${ }^{2}$ Physically effective NDF; calculated as material retained on top 2 screens $\times$ NDF in ration (Yang et al., 2001).

${ }^{3} \mathrm{GMPL}=$ geometric mean particle length calculated (Armentano and Taysom, 2005) as follows: GMPL (mm)

$=0.54+11.84 \times($ proportion $>9 \mathrm{~mm}$ in TMR $)$.

\section{Association of Particle Size Classes with Individual Lactation Curves}

To estimate particle size class effect on individual lactation curves, a multiple-lactation, single-trait random regression TD model was fitted to the production data combined with the TMR particle size information coming from the 25 farms involved in the study. Because TD records were collected monthly, whereas TMR were sampled every 3 mo, each TD record was associated with the closest TMR fed to animals immediately before or after the test day. Before this analysis, variance components for the genetic effects were estimated using a larger full data set of production data from 9,809 animals in 42 herds. Production TD records for the full data set were processed using a multiple-lactation, single-trait random regression TD model, with age at calving $\times$ year of calving, parity $\times$ stage of pregnancy, year of test $\times$ month of test set as fixed effects, and herd $\times$ test date, sire and maternal grandsire additive genetic effect, and permanent environmental effect set as random effects modeled using third-order Legendre polynomials (Caccamo et al., 2012). Model fitting was carried out using ASREML (Gilmour et al., 2009). Estimated variance components were then used to investigate the effect of TMR particle size classes on milk, fat, and protein yield lactation curves. An extension of the model used for variance components estimation was fitted, including TMR particle size class effect modeled as an interaction with DIM using a ninth-order Legendre polynomial to increase the sensitivity to dietary effects across DIM. To account for TMR chemical composition (which may confound effects of particle size), CP, NDF, and starch and their interaction with DIM (fitted as a ninth-order Legendre polynomial) were also included in the model. Significance of effects was tested using the conditional Wald F statistic (Gilmour et al., 2009).

Parameters estimated in the model were used to generate lactation curves for milk, fat, and protein yields for each class of TMR particle size (Gilmour et al., 2004). To have pure estimates of particle distribution not confounded by nutrient content of TMR, predictions of lactation curves per particle size class were controlled for TMR chemical composition. As the range in nutrient content of the TMR within class overlapped sufficiently, we determined that production data could be controlled for $\mathrm{CP}$ content of $15.5 \%$, NDF of $40.7 \%$, and starch of $19.7 \%$ for all classes. Mean production values for predicted lactation curves were tested for differences across particle size classes.

\section{RESULTS AND DISCUSSION}

\section{Chemical Characteristics of Diets}

A total of 148 TMR samples with sieve and composition analysis were available from 25 farms. Table 1 presents the mean ration composition and PSPS distributions for the 25 farms. Across all TMR samples, mean CP, NDF, and starch content were 15.2, 40.7, and $19.7 \%$, respectively (Table 1). By controlling for CP, $\mathrm{NDF}$, and starch, the production effects found in the current study are pure estimates of particle distribution not confounded by nutrient content of TMR.

We observed differences in the least squares means nutrient content and particle distributions for the classes (Table 2). Of all major nutrients, $\mathrm{CP}$ varied the most across particle size classes and we found only 
trends for differences in NDF and starch content $(P<$ 0.09). In general, diets that had the greatest proportion of TMR on the 19_PSPS sieve had the greatest mean values for NDF and the lowest $\mathrm{CP}$ and starch contents of the TMR samples. The contents of NDF and starch would be expected to support only a moderate level of milk production, 25 to $35 \mathrm{~kg}$ of milk, depending on DMI. With NDF content of $40.7 \%$ and given estimates of optimal NDF intake of approximately $1.25 \%$ of BW (Mertens, 2010), maximal DMI would be 19.2 to 20.8 $\mathrm{kg} / \mathrm{d}$ for BW of 600 to $650 \mathrm{~kg}$. Dry matter intake on Ragusa dairy farms is approximately 20 to $21 \mathrm{~kg} / \mathrm{d}$ (G. Azzaro, personal observation), so this seems reasonable given the NDF content of diets. Mertens (1997) suggests a maximal intake of $1.1 \%$ of peNDF, but given the peNDF estimate of $19.8 \%$ based on the PSPS particle distribution, this would correspond to maximal intakes of 31 to $35 \mathrm{~kg} / \mathrm{d}$, an amount unlikely in Ragusa. Of course, milk production also influences DMI, as do body size and DIM (NRC, 2001); therefore, milk production may also be a factor limiting intakes in Ragusa.

\section{Physical Characteristics of Diets}

The partitioning of diets into classes based on the top 2 PSPS screens is presented in Table 2. The proportion of the TMR on the 19_PSPS, 8_PSPS, 1.18_PSPS, and pan differed across classes, as expected by the classification scheme. Heinrichs and Kononoff (2002) recommend that the 19_PSPS screen contain 2 to $8 \%$ of TMR, which was the basis of choosing $<10.4$ as the first cut-off for the TMR classes. Second, it is recommended that the 8_PSPS sieve contain 30 to $50 \%$ of the TMR. We choose to categorize the 8 _PSPS screen based on $<30.1 \%$ for too short, 30.1 to $35.6 \%$, for intermediate, and $>35.6 \%$ for long. Because it is recommended that the bottom pan contain up to $20 \%$ feed material and the 8_PSPS and 1.18_PSPS screens contain 30 to 50\% of feed material, when the 19_PSPS screen cut point is set to $10 \%$, to meet these guidelines, the 8_PSPS and 1.18_PSPS sieves must each retain 35\% of the feed material. Thus, $35.6 \%$ was chosen as the boundary for defining the 8_PSPS screen categories. For classes 1 to 3, the 1.18_PSPS and bottom sieve proportions were fixed at 39.0 and $18.1 \%$, respectively. For classes 4 to 6, the 1.18_PSPS and bottom sieve values were set to 35.0 and $16.2 \%$, and for classes 7 to 9 , the 1.18_PSPS and bottom sieve proportions were set to 32.2 and $14.3 \%$. These were mean values for the sieve proportions within these classes.

In general, nutritionists are concerned when the 19_PSPS sieve contains more than $10 \%$ material because of the sorting that may occur when this is excessive. Maulfair et al. (2010) observed that cows ate less

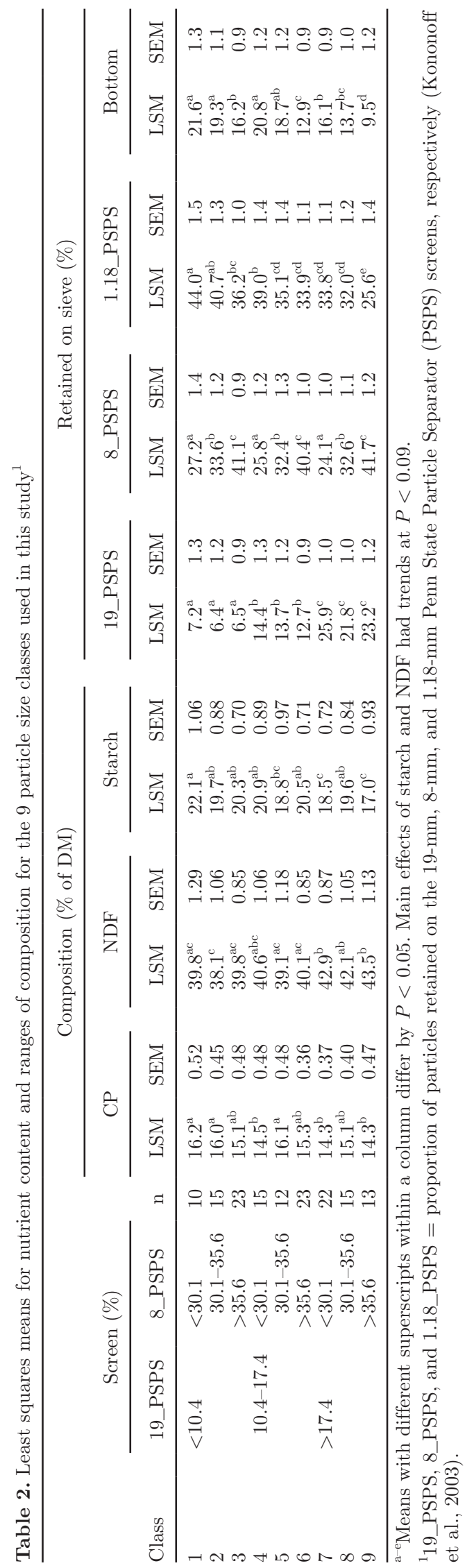


Table 3. Least squares means for geometric mean particle length (GMPL) and physically effective NDF (peNDF) based on particle sizes classes for the top 2 PSPS sieves

\begin{tabular}{|c|c|c|c|c|c|c|}
\hline \multirow[b]{2}{*}{ Class } & \multicolumn{2}{|c|}{ Screen $^{1}(\%)$} & \multicolumn{2}{|c|}{ peNDF $^{2}$} & \multicolumn{2}{|c|}{$\mathrm{GMPL}^{3}$} \\
\hline & 19_PSPS & 8_PSPS & LSM & SEM & LSM & SEM \\
\hline 1 & $<10.4$ & $<30.1$ & $13.7^{\mathrm{a}}$ & 1.08 & $4.6^{\mathrm{a}}$ & 0.23 \\
\hline 2 & & $30.1-35.6$ & $15.4^{\mathrm{a}}$ & 0.94 & $5.3^{\mathrm{b}}$ & 0.19 \\
\hline 3 & & $>35.6$ & $18.9^{\mathrm{c}}$ & 0.75 & $6.2^{\mathrm{c}}$ & 0.15 \\
\hline 4 & $10.4-17.4$ & $<30.1$ & $16.2^{\mathrm{ab}}$ & 0.98 & $5.3^{\mathrm{b}}$ & 0.20 \\
\hline 5 & & $30.1-35.6$ & $18.0^{\mathrm{bc}}$ & 1.02 & $6.0^{\mathrm{c}}$ & 0.21 \\
\hline 6 & & $>35.6$ & $21.5^{\mathrm{d}}$ & 0.76 & $6.8^{\text {de }}$ & 0.16 \\
\hline 7 & $>17.4$ & $<30.1$ & $21.6^{\mathrm{d}}$ & 0.79 & $6.5^{\mathrm{cd}}$ & 0.16 \\
\hline 8 & & $30.1-35.6$ & $23.0^{\mathrm{d}}$ & 0.86 & $7.0^{\mathrm{e}}$ & 0.17 \\
\hline 9 & & $>35.6$ & $28.2^{\mathrm{e}}$ & 0.99 & $8.2^{\mathrm{f}}$ & 0.20 \\
\hline
\end{tabular}

${ }^{\mathrm{a}-\mathrm{f}}$ Means with different superscripts within a column differ by $P<0.05$.

${ }_{1}^{1}$ 19_PSPS and 8_PSPS = proportion of particles retained on the 19-mm and 8-mm Penn State Particle Separator (PSPS) screens, respectively (Kononoff et al., 2003).

${ }^{2}$ peNDF $=$ sum of TMR particles collected on the upper $(19 \mathrm{~mm})$ and middle $(9 \mathrm{~mm})$ sieves $\times$ the NDF content of the TMR (Yang et al., 2001).

${ }^{3}$ GMPL calculated (Armentano and Taysom, 2005) as follows: GMPL $(\mathrm{mm})=0.54+11.84 \times($ proportion $>9$ $\mathrm{mm}$ in TMR).

chopped grass hay when $11.7 \%$ of the particles were retained on a $26.9-\mathrm{mm}$ sieve compared with $8.6 \%$ or lower. Thus, cows are very selective with just a small increment in particle size associated with the proportion of material retained on the top screen. If intake of longer particles decreases, then intake of shorter particles increases, particularly of particles in the bottom pan (Maulfair et al., 2010). In their study, the effect due to sorting was that cows ate less NDF and more starch than offered in the TMR when more long particles were present in the diet.

Least squares means for GMPL are presented in Table 3. Recommendations in Heinrichs and Kononoff (2002) include that $<20 \%$ of the TMR be in the bottom pan. Classes 1 and 4 (Table 2) had least squares means values of $>20 \%$ in the bottom pan. Class 1 diets had the lowest least squares means GMPL, $4.6 \mathrm{~mm}$ (SEM 0.2), and class $2(5.3 \mathrm{~mm}$, SEM 0.2) and class 4 (5.3 mm, SEM 0.2) had the next lowest mean GMPL estimates. All other classes had least squares means GMPL from 6.0 to $8.2 \mathrm{~mm}$. We are not aware of a recommendation for a mean GMPL score for a TMR. General recommendations are that the diet contains 19 to $21 \%$ peNDF on a DM basis or that forage NDF comprises $75 \%$ or more of total NDF (NRC, 2001). The overall mean value for peNDF was 19.8 , within NRC (2001) ranges. However, peNDF for class 1 TMR was 13.7 (SEM 0.9) and only $>21 \%$ for classes 6 through 9 (Table 3). For peNDF, the lowest mean GMPL was for diets of class 1 and the longest was for diets from class 6 and greater. Class 3 and class 5 diets were intermediate in length between the shortest 3 classes (classes 1 , 2, and 4) and the longest classes (class 6 and higher; Table 3).
Most studies investigating particle size have used silages with chopped hay as forage components. In Sicily, forages on farms are typically a mixture of long hay and silage, either triticale or corn silage. The hay is usually a mature grass, greater than $60 \% \mathrm{NDF}$ and $10 \%$ or less in CP, and is harvested once in May. In herds that feed a TMR, hay is added into the mixer wagon as long material, resulting in longer particle size than typical for chopped or ground hays. Concentrate mixes are usually a composite of ground corn and at times some barley grain, soybean meal or sunflower meal, beet pulp, a rumen-protected fat, and minerals and vitamins. Some farms will supplement with fresh citrus pulp, but this is only available from January through April. Flaked soybeans and wheat bran may also be included in concentrate mixes but these are not used routinely. Particle size of TMR tends to be coarse and total NDF tends to be higher than observed on US dairy farms.

\section{Particle Size Class Effect on Herd-Level Milk and Milk Components Yield}

Mean herd-level production for milk, fat, and protein of the 25 herds included in this study are presented in Table 4. In general, for all traits, production was lowest for 8_PSPS screen proportion $>35.6$ within each top screen proportion class (classes 3, 6, 9 in Table 4). Differences were not significant, but within the 3 groupings based on the retention of material on the 19_PSPS screen, peNDF was greatest when material retained on the 8_PSPS screen was $>35.6 \%$ of the TMR. Within each class, more material retained on the 8_PSPS screen resulted in less fine material retained 
Table 4. Least squares means for milk, fat, and protein yield for the 9 particle size classes used in this study

\begin{tabular}{|c|c|c|c|c|c|c|c|c|}
\hline \multirow[b]{2}{*}{ Class } & \multicolumn{2}{|c|}{ Screen $^{1}(\%)$} & \multicolumn{2}{|c|}{ Milk (kg) } & \multicolumn{2}{|c|}{ Fat $(\mathrm{g})$} & \multicolumn{2}{|c|}{ Protein $(\mathrm{g})$} \\
\hline & 19_PSPS & 8_PSPS & LSM & SEM & LSM & SEM & LSM & SEM \\
\hline 1 & $<10.4$ & $<30.1$ & $29.3^{\mathrm{a}}$ & 0.10 & $1,102.5^{\mathrm{d}}$ & 3.98 & $1,032.7^{\mathrm{bc}}$ & 4.45 \\
\hline 2 & & $30.1-35.6$ & $34.6^{\mathrm{b}}$ & 0.14 & $1,179.8^{b}$ & 5.57 & $1,057.0^{\mathrm{a}}$ & 4.71 \\
\hline 3 & & $>35.6$ & $27.6^{\mathrm{e}}$ & 0.21 & $1,008 \cdot 0^{f}$ & 8.13 & $990.9^{\mathrm{e}}$ & 6.55 \\
\hline 4 & $10.4-17.4$ & $<30.1$ & $35.7^{\mathrm{a}}$ & 0.10 & $1,241.3^{\mathrm{a}}$ & 4.00 & $1,017.8^{\mathrm{a}}$ & 4.46 \\
\hline 5 & & $30.1-35.6$ & $32.7^{\mathrm{c}}$ & 0.14 & $1,109.1^{\mathrm{d}}$ & 5.43 & $1,009.7^{\mathrm{d}}$ & 4.85 \\
\hline 6 & & $>35.6$ & $32.9^{\mathrm{c}}$ & 0.15 & $1,139.5^{\mathrm{c}}$ & 6.06 & $1,013.6^{\mathrm{d}}$ & 6.82 \\
\hline 7 & $>17.4$ & $<30.1$ & $30.5^{\mathrm{d}}$ & 0.15 & $1,065.6^{\mathrm{e}}$ & 5.73 & $1,054.5^{\mathrm{a}}$ & 5.39 \\
\hline 8 & & $30.1-35.6$ & $30.2^{\mathrm{d}}$ & 0.14 & $1,074.1^{\mathrm{e}}$ & 5.58 & $1,034.1^{\mathrm{b}}$ & 4.46 \\
\hline 9 & & $>35.6$ & $27.4^{\mathrm{e}}$ & 0.12 & $964.0^{\mathrm{g}}$ & 4.86 & $1,020.4^{\mathrm{cd}}$ & 5.08 \\
\hline
\end{tabular}

${ }^{\mathrm{a}-\mathrm{g}}$ Means with different superscripts within a column differ by $P<0.05$.

19_PSPS and 8_PSPS $=$ proportion of particles retained on the 19-mm and 8-mm Penn State Particle Separator (PSPS) screens, respectively (Kononoff et al., 2003).

on the 1.18_PSPS screen and passing to the pan. These rations had longer mean GMPL and were coarser than the other diets within each class. Yang and Beauchemin (2007) observed that chewing activity was most correlated with the proportion of material retained on the top 2 sieves of the PSPS.

\section{Particle Size Class Effect on Individual Lactation Curves}

Figures 1, 2, and 3 present the influence of particle proportion classes on milk yield (kg, Figure 1), fat yield (g/d, Figure 2), and protein yield (g/d, Figure 3). We observed little effect of class of particle proportions on the top 2 sieves and peNDF on milk yield and fat yield. In general, milk yield and fat yield tended to be slightly greater as class increased from class 1 to class 9 (Table 5). The proportion of particles retained on the top 2 PSPS sieves that were associated with peNDF greater than $21.0 \%$ of DM had the highest milk and fat yields. However, class 4, with particle retention on the 19_PSPS sieve of 10.4 to $17.4 \%$ and 8_PSPS screen of $<30.1 \%$, and a peNDF of 16.0 had high milk yield and fat yield compared with other yields in classes 1

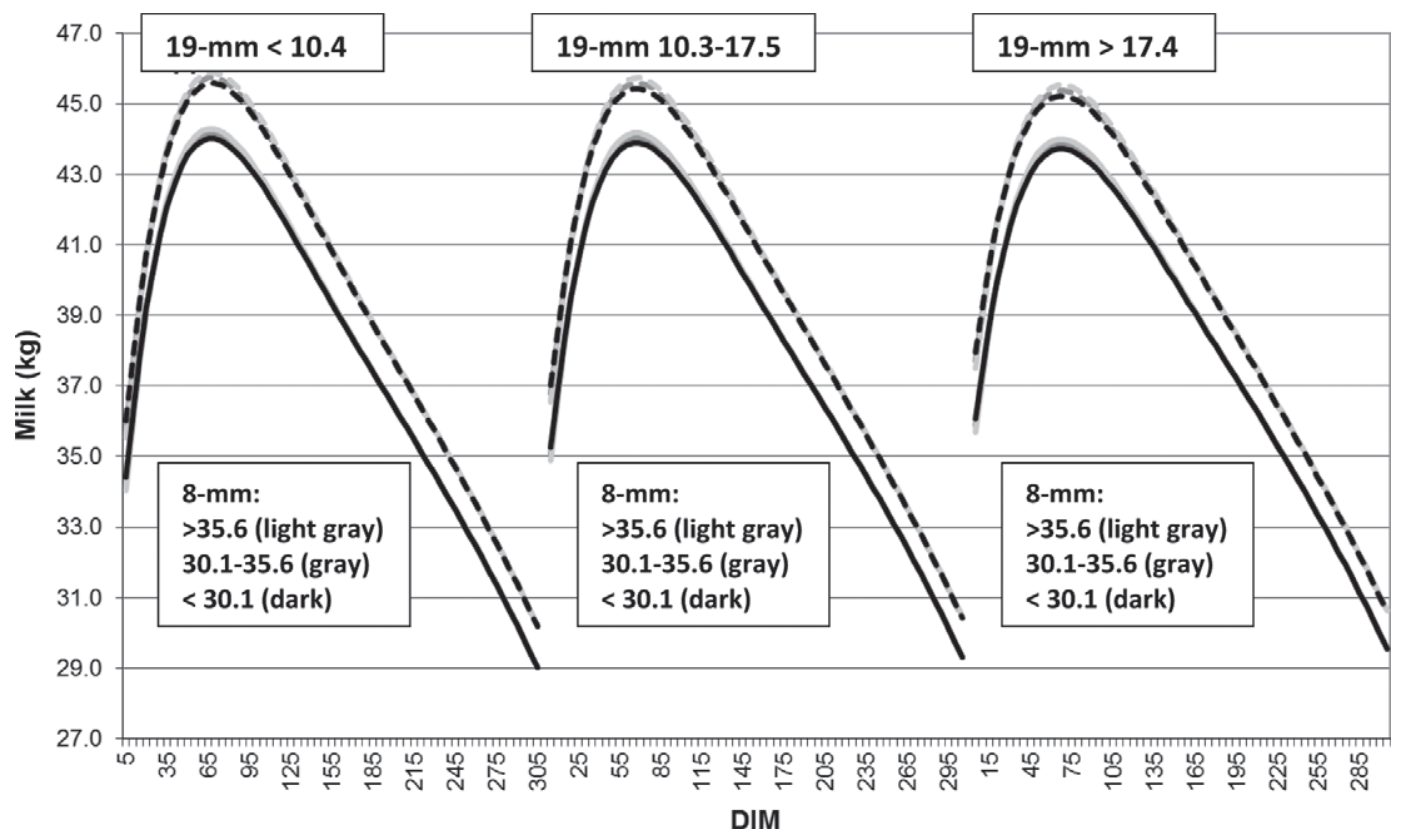

Figure 1. Milk production curves for classes of TMR categorized by particle retention on the Penn State Particle Separator. Diets were categorized into 9 classes based on proportion of particles retained on the upper sieve $(19 \mathrm{~mm})$ and the middle sieve $(8 \mathrm{~mm})$. Classes were as follows: 19-mm sieve particles: $<10.4 \%, 10.4-17.4 \%,>17.4 \%$; 8 -mm sieve: $<30.1 \%, 30.1-35.6 \%,>35.6 \%$. Dashed curves are for univariate model for classes of particle separation, solid curves are multivariate models including covariates for mean CP concentration of TMR, 15.5\%, starch, $19.7 \%$, and NDF, $40.7 \%$, and their interaction with DIM. 
Table 5. Mean production values based on curves in Figures 1, 2, and 3 for outputs from the test-day model controlling for 9 classes of particle size based on particles in TMR retained on the top 2 Penn State Particle Separator (PSPS) sieves (19 and $8 \mathrm{~mm}$ )

\begin{tabular}{lccccccccc}
\hline & & \multicolumn{2}{c}{ Milk $(\mathrm{kg})$} & & \multicolumn{2}{c}{ Fat $(\mathrm{g})$} & & \multicolumn{2}{c}{ Protein $(\mathrm{g})$} \\
\cline { 3 - 4 } \cline { 8 - 9 } Class $^{1}$ & peNDF $^{2}$ & Mean & SEM & & Mean & SEM & & Mean & SEM \\
\hline 1 & 13.7 & 38.0 & 0.02 & & $1,244.5$ & 1.3 & & $1,165.2$ & 1.8 \\
2 & 15.9 & 38.0 & 0.02 & & $1,241.4$ & 1.3 & & $1,162.1$ & 1.8 \\
3 & 18.7 & 38.0 & 0.02 & & $1,238.2$ & 1.3 & & $1,159.0$ & 1.8 \\
4 & 16.0 & 38.2 & 0.02 & & $1,248.1$ & 1.3 & & $1,248.1^{*}$ & 1.8 \\
5 & 18.0 & 38.2 & 0.02 & & $1,245.0$ & 1.3 & & $1,245.0^{*}$ & 1.8 \\
6 & 21.9 & 38.2 & 0.02 & & $1,241.9$ & 1.3 & & $1,241.9^{*}$ & 1.8 \\
7 & 21.2 & 38.4 & 0.02 & & $1,249.6$ & 1.3 & & $1,158.2$ & 1.8 \\
8 & 23.4 & 38.3 & 0.02 & & $1,246.5$ & 1.3 & & $1,155.2$ & 1.8 \\
9 & 28.2 & 38.3 & 0.02 & & $1,243.4$ & 1.3 & & $1,152.1$ & 1.8 \\
\hline
\end{tabular}

${ }^{1}$ Classes defined as in Table 2 .

${ }^{2}$ Physically effective NDF.

$* P<0.05$ (means differed between 19-mm PSPS classes).

to 3 and classes 4 and 5 (Table 5). Overall effects were minor on milk yield and fat yield, so trends should be viewed cautiously.

Of interest is the effect of sieve classes on protein yield. Protein yield was greater for sieve classes 4,5 , and 6, all sieve classes with 10.4 to $17.4 \%$ of TMR particles retained on the 19_PSPS sieve (Table 5, Figure 3). Sieve classes that retained more than $17.4 \%$ of particles on the 19_PSPS sieve had the lowest protein yields. In this data set, protein yields were enhanced when the 19_PSPS sieve contained 10.4 to $17.4 \%$ particles, irrespective of the 8_PSPS sieve proportions. Dietary CP was $15.5 \%$, starch was $19.7 \%$, and NDF was $40.7 \%$ for the analysis. This result was surprising. Only Kononoff and Heinrichs (2003a,b) observed an influence of particle size on protein content in milk. Most studies examining particle size have not found an effect on milk protein yield or content (Krause et al., 2002; Beauchemin et al., 2003; Krause and Combs, 2003; Bhandari et al., 2007, 2008). Because nutrient

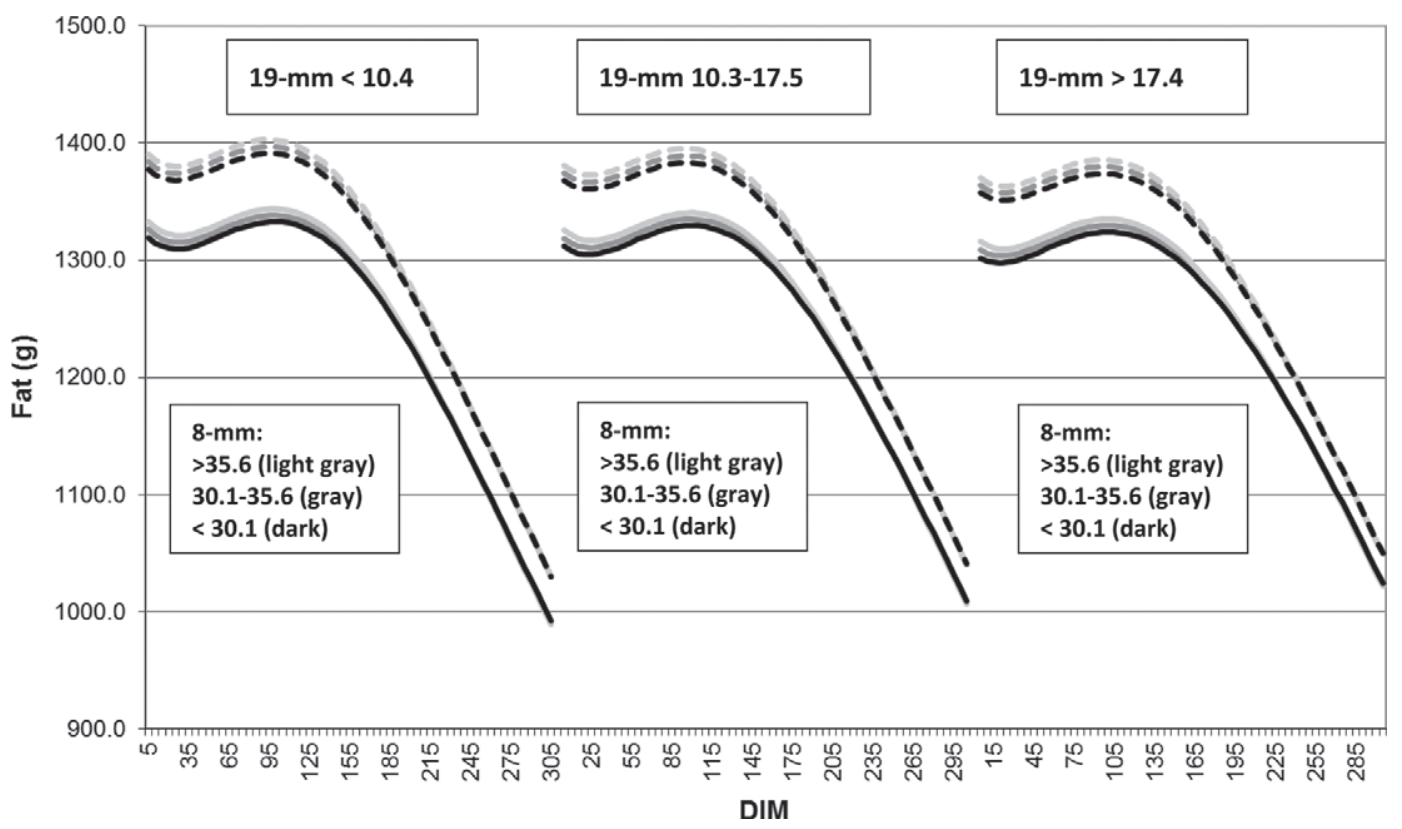

Figure 2. Fat production curves for classes of TMR categorized by particle retention on the Penn State Particle Separator. Diets were categorized into 9 classes based on proportion of particles retained on the upper sieve $(19 \mathrm{~mm})$ and the middle sieve ( $8 \mathrm{~mm})$. Classes were as follows: 19 -mm sieve particles: $<10.4 \%, 10.4-17.4 \%,>17.4 \% ; 8-\mathrm{mm}$ sieve: $<30.1 \%, 30.1-35.6 \%,>35.6 \%$. Dashed curves are for univariate model for classes of particle separation, solid curves are multivariate models including covariates for mean CP concentration of TMR, $15.5 \%$, starch, $19.7 \%$, and NDF, $40.7 \%$, and their interaction with DIM. 


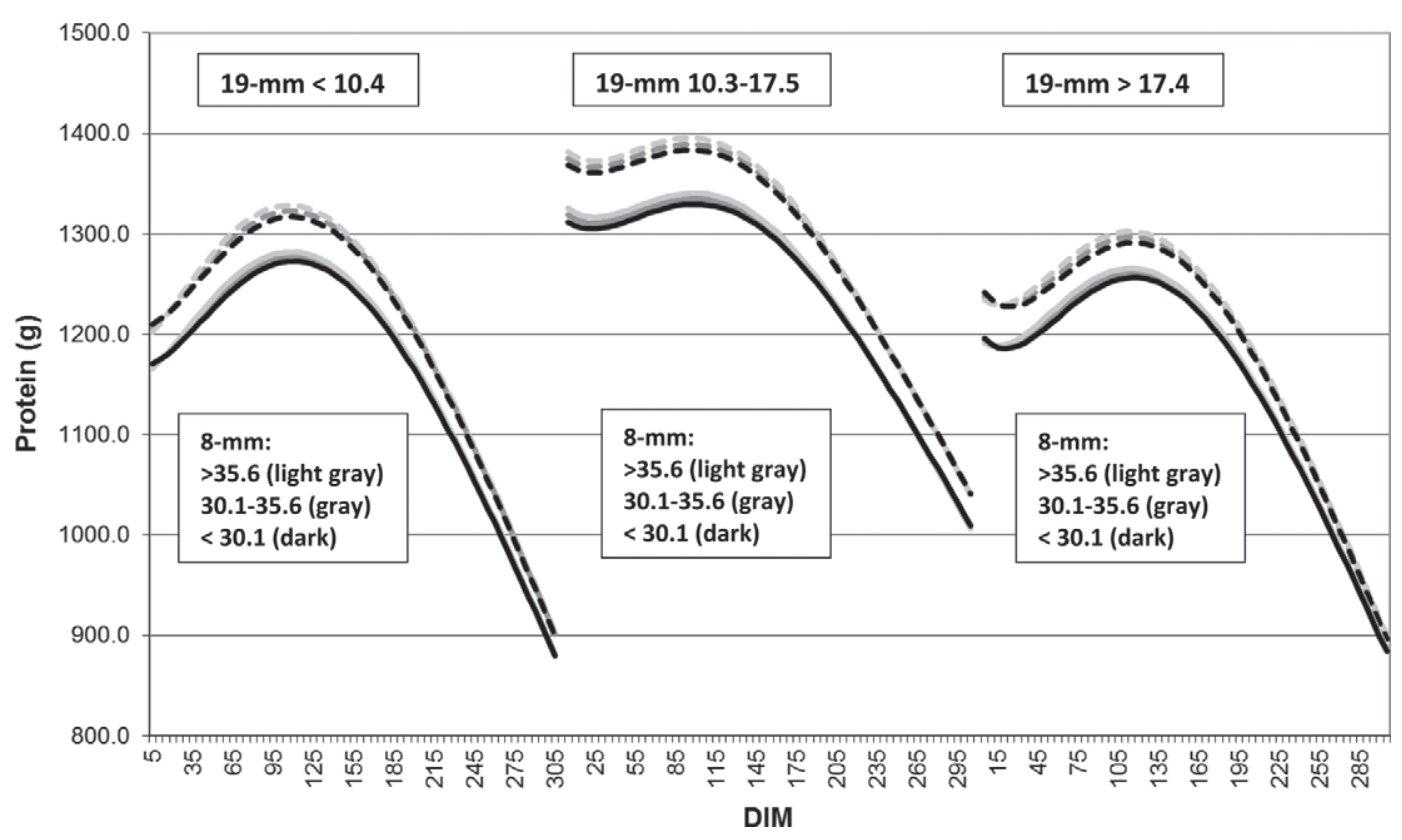

Figure 3. Protein production curves for classes of TMR categorized by particle retention on the Penn State Particle Separator. Diets were categorized into 9 classes based on proportion of particles retained on the upper sieve $(19 \mathrm{~mm})$ and the middle sieve ( $8 \mathrm{~mm})$. Classes were as follows: 19 -mm sieve particles: $<10.4 \%, 10.4-17.4 \%,>17.4 \% ; 8$-mm sieve: $<30.1 \%, 30.1-35.6 \%,>35.6 \%$. Dashed curves are for univariate model for classes of particle separation, solid curves are multivariate models including covariates for mean CP concentration of TMR, $15.5 \%$, starch, $19.7 \%$, and NDF, $40.7 \%$, and their interaction with DIM.

content was controlled in the analysis, we may speculate that sieve classes with 10.4 to $17.4 \%$ of particles on the top screen were associated with the most uniform intake of nutrients, resulting in an influence on protein yield in milk. Within this class of particle sizes (classes 4, 5, and 6; Table 2), the 1.18_PSPS screen and pan had approximately $59.8,53.8$, and $46.8 \%$ of TMR material. In classes 1, 2, and 3, TMR had 65.6, 60.0 , and $52.0 \%$ of material on the 1.18_PSPS screen and pan, whereas classes 7, 8, and 9 had 49.9, 45.7, and $35.1 \%$ of material on the 1.18_PSPS screen and pan. Therefore, the middle classes $(4,5$, and 6$)$ had the most consistent distribution of fine particles relative to the recommendations in Heinrichs and Kononoff (2002) of 30 to $50 \%$ of material on the 1.18_PSPS screen and $20 \%$ of material in the pan. This may have resulted in the most uniform intake of nutrients of the 3 classes.

\section{CONCLUSIONS}

Based on this study, particle size distributions in Ragusa dairy farm TMR were associated with small but significant effects on milk protein yield. The distribution most associated with increased protein yield was when the 19_PSPS screen contained 10.4 to $17.4 \%$ of TMR particles and the 1.18_PSPS screen and pan contained 45 to $59 \%$ of TMR particle weight. Particle size distributions maximizing production of milk and milk components were different than those recommended in the literature and may reflect regional differences based on climate and types and quality of forages fed.

\section{ACKNOWLEDGMENTS}

Financial support was provided by the Assessorato Agricoltura e Foreste della Regione Siciliana (Palermo, Italy).

\section{REFERENCES}

Allen, M. S. 1997. Relationship between fermentation acid production in the rumen and the requirement for physically effective fiber. J. Dairy Sci. 80:1447-1462.

AOAC International. 1998. Official Methods of Analysis. 4th rev. 16th ed. AOAC International, Arlington, VA.

Armentano, L. E., and D. Taysom. 2005. Short communication: Prediction of mean particle size and proportion of very long fiber particles from simplified sieving results. J. Dairy Sci. 88:3982-3985.

Balch, C. C. 1971. Proposal to use time spent chewing as an index of the extent to which diets for ruminants possess the physical property of fibrousness characteristic of roughages. Br. J. Nutr. 26:383-392.

Beauchemin, K. A., W. Z. Yang, and L. M. Rode. 2003. Effects of particle size of alfalfa-based dairy cow diets on chewing activity, ruminal fermentation, and milk production. J. Dairy Sci. 86:630-643.

Bhandari, S. K., S. Li, K. H. Ominski, K. M. Wittenberg, and J. C. Plaizier. 2008. Effects of the chop lengths of alfalfa silage and oat silage on feed intake, milk production, feeding behavior, and rumen fermentation of dairy cows. J. Dairy Sci. 91:1942-1958.

Bhandari, S. K., K. H. Ominski, K. M. Wittenberg, and J. C. Plaizier. 2007. Effects of chop length of alfalfa and corn silage on milk production and rumen fermentation of dairy cows. J. Dairy Sci. 90:2355-2366. 
Caccamo, M., R. F. Veerkamp, G. Licitra, R. Petriglieri, F. La Terra, A. Pozzebon, and J. D. Ferguson. 2012. Association of total-mixedration chemical composition with milk, fat, and protein yield lactation curves at individual level. J. Dairy Sci. 95:6171-6183.

Gilmour, A., B. Cullis, S. Welham, B. Gogel, and R. Thompson. 2004 An efficient computing strategy for prediction in mixed linear models. Comput. Stat. Data Anal. 44:571-586.

Gilmour, A. R., B. J. Gogel, B. R. Cullis, and R. Thompson. 2009 ASReml User Guide. NSW Department of Primary Industries, Orange, Australia.

Goering, H. K., and P. J. Van Soest. 1970. Forage fiber analysis (apparatus, reagent, procedures and some applications). Agriculture Handbook No. 379. US Department of Agriculture, Washington, DC.

Grant, R. J., and V. F. Colenbrander. 1990a. Milk fat depression in dairy cows: Role of particle size of alfalfa hay. J. Dairy Sci. $73: 1823-1833$.

Grant, R. J., and V. F. Colenbrander. 1990b. Milk fat depression in dairy cows: Role of silage particle size. J. Dairy Sci. 73:1834-1842.

Heinrichs, A. J., and P. J. Kononoff. 2002. Evaluating particle size of forages and TMRs using the new Penn State Forage Particle Separator. Penn State Coop. Ext., Coll. Agric. Sci. 42:1-15.

Kononoff, P. J., and A. J. Heinrichs. 2003a. The effect of corn silage particle size and cottonseed hulls on cows in early lactation. J. Dairy Sci. 86:2438-2451.

Kononoff, P. J., and A. J. Heinrichs. 2003b. The effect of reducing alfalfa haylage particle size on cows in early lactation. J. Dairy Sci. 86:1445-1457.

Kononoff, P. J., A. J. Heinrichs, and D. R. Buckmaster. 2003. Modification of the Penn State forage and total mixed ration particle separator and the effects of moisture content on its measurements. J. Dairy Sci. 86:1858-1863.

Krause, K. M., and D. K. Combs. 2003. Effects of forage particle size, forage source, and grain fermentability on performance and ruminal pH in midlactation cows. J. Dairy Sci. 86:1382-1397.

Krause, K. M., D. K. Combs, and K. A. Beauchemin. 2002. Effects of forage particle size and grain fermentability in midlactation cows I. Milk production and diet digestibility. J. Dairy Sci. 85:19361946.

Lammers, B. P., D. R. Buckmaster, and A. J. Heinrichs. 1996. A simple method for the analysis of particle sizes of forage and total mixed rations. J. Dairy Sci. 79:922-928.
Licitra, G., T. M. Hernandez, and P. J. Van Soest. 1996. Standardization of procedures for nitrogen fractionation of ruminant feeds. Anim. Feed Sci. Technol. 57:347-358.

Maulfair, D. D., and A. J. Heinrichs. 2010. Technical note: Evaluation of procedures for analyzing ration sorting and rumen digesta particle size in dairy cows. J. Dairy Sci. 93:3784-3788.

Maulfair, D. D., G. I. Zanton, M. Fustini, and A. J. Heinrichs. 2010. Effect of feed sorting on chewing behavior, production, and rumen fermentation in lactating dairy cows. J. Dairy Sci. 93:4791-4803.

Mertens, D. R. 1997. Creating a system for meeting the fiber requirements of dairy cows. J. Dairy Sci. 80:1463-1481.

Mertens, D. R. 2002. Gravimetric determination of amylase-treated neutral detergent fiber in feeds using refluxing in beakers or crucibles: Collaborative study. J. AOAC Int. 85:1217-1240.

Mertens, D. R. 2010. NDF and MDI-Has anything changed? Proc. Cornell Nutr. Conf., Syracuse, NY. Pp: 160-174.

NRC. 2001. Nutrient Requirements of Dairy Cattle. 7th rev. ed. Natl. Acad. Press, Washington, DC.

Poppi, D. P., B. W. Norton, D. J. Minson, and R. E. Hendricksen. 1980. The validity of the critical size theory for particles leaving the rumen. J. Agric. Sci. 94:275-280.

Schadt, I., J. D. Ferguson, G. Azzaro, R. Petriglieri, M. Caccamo, P. Van Soest, and G. Licitra. 2012. How do dairy cows chew?-Particle size analysis of selected feeds with different particle length distributions and of respective ingested bolus particles. J. Dairy Sci. 95:4707-4720.

Van Soest, P. J., J. B. Robertson, and B. A. Lewis. 1991. Methods for dietary fiber, neutral detergent fiber, and nonstarch polysaccharides in relation to animal nutrition. J. Dairy Sci. 74:3583-3597.

Woodford, S. T., and M. R. Murphy. 1988. Dietary alteration of particle breakdown and passage from the rumen in lactating dairy cattle. J. Dairy Sci. 71:687-696.

Yang, W. Z., and K. A. Beauchemin. 2007. Altering physically effective fiber intake through forage proportion and particle length: Chewing and ruminal pH. J. Dairy Sci. 90:2826-2838.

Yang, W. Z., K. A. Beauchemin, and L. M. Rode. 2001. Effects of grain processing, forage to concentrate ratio, and forage particle size on rumen $\mathrm{pH}$ and digestion by dairy cows. J. Dairy Sci. $84: 2203-2216$ 